\title{
A MODEL FOR THE STUDY OF READING IN AGRISCIENCE
}

\author{
Travis D. Park, Assistant Professor \\ Cornell University \\ Ed Osborne, Professor and Chair \\ University of Florida
}

\begin{abstract}
Agriscience is facing pressure to document and contribute to student achievement in math, science, and reading. Agriscience teachers may be able to foster student reading and comprehension through utilization of research-based reading strategies to further develop literacy in and about agriculture. Building on Dunkin and Biddle's (1974) model of the study of teaching, this synthesis of research proposes areas of inquiry regarding the teacher and context variables associated with reading. Teachers influence reading in agriscience through personal reading habits, expectations for reading, attitudes toward reading, and knowledge of and preparation in reading strategy use. Contextual variables include the student, environment, and text. Students enter agriscience classes with differing reading ability, interest, prior knowledge, prior reading, motivation, age, and experience. They encounter texts in the home, classroom, and school environments. Texts are comprised of varying readability, vocabulary, structure, content, and selection, all of which impact comprehension.
\end{abstract}

\section{Introduction}

Today's students must possess high degrees of literacy in many different areas (Snow, 2002) for successful careers, citizenry, and personal lives (D'Arcangelo, 2002; Meltzer, 2001), Today's students will read and write more than students from any other era (Moore, Bean, Birdyshaw, \& Rycik, 1999). They need higher order literacy skills to analyze and comprehend the plethora of knowledge and facts available today (Moore et al., 1999; Vacca, 2002).

Although most secondary students have learned to read, content area reading, including reading in agriscience, demands skills beyond those used in earlier grades. Content area reading is difficult because of hourly class changes, shifts in content knowledge, and sophisticated texts and information (Bryant, Ugel, \& Thompson, 1999; D'Arcangelo, 2002; Meltzer, 2001; Snow, 2002). Because much reading time is consumed with uninteresting, difficult assigned readings, students develop poor attitudes toward and lose interest in reading
(Moore et al., 1999; Readence, Bean, \& Baldwin, 1989). The decline in intensive instruction in content area reading and reinforcement of reading strategies throughout formal schooling (Forget \& Bottoms, 2000; Meltzer) contributes to the widening range of reading abilities (Baer \& Nourie, 1993).

Thus, all teachers, including agriscience teachers, share responsibility for promoting and developing active, purposeful readers, as well as teaching students to use applicable reading strategies (Rhoder, 2002; Vacca, 2002). While content area teachers may not be expected to teach reading, they are expected to facilitate reading processes (Bean, 1997; McKenna \& Robinson, 2002). Enhancing literacy skills improves learning and comprehension in content areas, including agriscience (Duke \& Pearson, 2002; Jacobs, 2002; Meltzer, 2001); yet, less than $14 \%$ of content area teachers reinforced reading strategies (Irvin \& Connors, 1989).

The need exists for integration of reading with agriscience, as agriscience teachers are increasingly being called upon to demonstrate contributions to student 
performance in reading and other core subjects (Belcher, McCaslin, \& Headley, 1996; Conroy \& Walker, 2000). Yet, what variables impact student achievement in reading in agriscience? How can teachers and researchers in agricultural education impact student reading comprehension in agriscience?

\section{Theoretical Framework}

Adolescents need well-developed reading instruction in content areas to improve comprehension (Meltzer, 2001; Moore et al., 1999). Content area reading emphasizes application, reading to learn, and comprehension of content area material (Baer \& Nourie, 1993). Bryant et al. (1999) clarified content area reading as "students interact[ing] with the text to interpret and construct meaning before, during, and after reading by using their prior knowledge and the skills and strategies developed during early reading instruction" (p. 293). Content area reading "frequently covers concepts that extend beyond the knowledge of many children and adds to this difficulty by introducing them in rapid-fire fashion" (Baer \& Nourie, p. 1).

Building on Dunkin and Biddle's (1974) model for classroom teaching, reading in agriscience involves the interplay of context, teacher, interaction, and outcome variables. The context includes the student and his or her environment. Teacher variables may encompass the teacher's values, attitudes, behaviors, preparation, and culture. Interactions comprise the activities taking place in the classroom, strategy use and instruction, and interactions between teachers and students. Outcomes of instruction include comprehension, learning, and growth. What specific variables should be studied to improve student achievement and motivation in reading and comprehension within the agriscience context?

\section{Purpose and Objectives}

The primary purpose for this synthesis of research was to develop a model for research about reading in agriscience. The objectives of the study were

1. to determine what teacher variables impact student reading in agriscience,

2. to determine what context variables impact student reading in agriscience, and

3. to develop a conceptual model for studying reading in agriscience.

\section{Procedures}

A library and Internet search was used to gather data for this synthesis of research. Several sources were used to gather data to meet the objectives of the study: the university library, Journal of Agricultural Education, ERIC Documentation Reproduction Service, and WebLUIS Indexes. References were located through library services at the University of Florida. Key words used in locating research included content area reading, secondary reading, content area literacy, and secondary literacy. Studies were reviewed based upon their titles, purposes, findings, and conclusions. The researchers grouped articles under themes related to teacher and context variables related to content area reading, specifically reading in agriscience. Teacher variables were defined as those variables under control or direct influence of the individual classroom teacher. Context variables were those variables associated with the students and classroom environment.

\section{Findings}

Fifty-seven resources contained research about content area reading. Thirty books, 32 journal articles, two ERIC documents, 
and six online articles, some of which related to both constructs, contained research in content area reading (Table 1).

Table 1

Total Number of Resources Addressing Content Area Reading

\begin{tabular}{lccccc} 
& Books & Journal Articles & ERIC & Online & Total \\
\hline Teacher Variables & 9 & 12 & 0 & 3 & 24 \\
Context Variables & 21 & 20 & 2 & 3 & 46 \\
\hline Total $^{\text {a }}$ & 30 & 32 & 2 & 6 & 70 \\
\hline
\end{tabular}

${ }^{a}$ Resources may be duplicated for teacher and context variables.

\section{Context Variables}

Context variables related to reading in agriscience include the student, his or her environment, and the text. Students bring a quantity of ability, interest, prior knowledge, experience, and motivation to the reading processes. The student encounters text within a larger environment encompassing the classroom, school, and home life. Texts possess characteristics that affect comprehension, including readability, vocabulary, structure, content, and selection.

\section{Student Variables}

Students' effort and ability to read must be analyzed to better understand reading capabilities. Agriscience teachers have difficulty in assessing student reading performance (Gartin, Varner-Friddle, Lawrence, Odell, \& Rinehart, 1994). Ongoing assessment of student use of strategies and their success is critical to ascertain students' comprehension and reading abilities (Duke \& Pearson, 2002). Student reading ability is difficult to ascertain and measure because many factors affect it (McKenna \& Robinson, 2002).

Research has indicated a positive relationship between interest and comprehension (Asher, 1980; Baldwin, Peleg-Bruckner, \& McClintock, 1985; Wigfield \& Asher, 1984). Students with natural curiosity and desire to learn are inclined to become actively engaged in texts (D’Arcangelo, 2002; Hurst, 2001; Snow, 2002). Curious students ask questions and make judgments about text, inferring about author's motives, ideas, and expected outcomes. Self-initiated questioning improves reading comprehension (Duke \& Pearson, 2002). Allowing adequate time and self-selection of reading materials boosts interest (Readence et al., 1989).

High interest leads to high motivation, which leads to high comprehension (Snow, 2002). Student motivation impacts whether and how a student will use comprehension strategies (Dole, Brown, \& Trathen, 1996; Guthrie et al., 1996; Pressley, Symons, McGoldrick, \& Snyder, 1995). Enduring interest in reading develops from competence, involvement, and enjoyment (Readence et al., 1989). Students who become more engaged in reading take more ownership of reading, thus improving motivation (Snow, 2002). Factors affecting motivation include expectancy, purpose, and incentives (McKenna \& Robinson, 2002). Developing purpose for reading is essential, so students search for and find key information to attain that purpose.

Comprehension improves when a student's prior knowledge is activated through pre-reading instruction (Cooper, 2000; Gaultney, 1995; Michiels-Bongaerts \& Schmidt, 1995; Pate, 1995; Ryder \& Graves, 1994). Prior knowledge depends on the reader's background, experience, and word knowledge from a variety of reading sources (Bryant et al., 1999; Snow, 2002). Students must consider prior knowledge to organize new information and make 
connections among schema (Collins, 1994; D'Arcangelo, 2002; Forget \& Bottoms, 2000; Friend, 2001; Rhoder, 2002; Snow). Prior knowledge must be activated for students to read effectively in content areas, or teachers must provide accurate background knowledge of specific topics (Jacobs, 2002; National Reading Panel, 2000; Pressley et al., 1995; Ryder \& Graves; Snider, 1989), as students do not often activate prior knowledge on their own prior to reading (Paris \& Lindauer, 1976). Activation is recommended for poor readers who may not spontaneously relate previous experience or knowledge to reading (Pressley et al.).

Metacognitive ability and strategic learning are related to age and reading experience (Stewart \& Tei, 1983). Students' age and volume of experiences related to subject matter affect their ability to make connections and develop relationships between existing and new knowledge. Reading ability increases with age and accumulation of life experiences from which to draw upon in activating prior knowledge (McKenna \& Robinson, 2002; Vacca, 2002). Students' self-concept is impacted by past reading performances (Stanovich, 1986).

\section{Environment}

Reading occurs in a larger socio-cultural context that shapes and is shaped by the reader (Snow, 2002). Socio-cultural contexts include economic resources, class membership, ethnicity, neighborhood, technology, and school culture. Text-rich home environments and family values in reading foster reading in adolescents (Readence et al., 1989; Ryder \& Graves, 1994). Students who discuss their lessons and reading at home score higher on standardized reading test scores (Donahue, Voelkl, Cambell, \& Mazzeo, 1999); yet in 1998, eighth- and twelfth-graders discussed reading less with peers than in 1992.

Student reading and learning environment affect attitudes toward reading (Meltzer, 2001, Snow, 2002). Volume and type of classroom reading resources affect student motivation to read (Ivey, 2002; Ryder \& Graves, 1994). Diversity of real reading resources communicates that reading is important, and content area concepts are not generated from a sole source (Ivey). Reading is enhanced if students are encouraged to read for pleasure and if readings are discussed rather than regurgitated for information. School cultures, which promote literacy, emphasize connection, interaction, and responsiveness, lead to student engagement (Collins, 1994; Moore, Alvermann, \& Hinchman, 2000; Schunk \& Zimmerman, 1997).

Text
Readers who possess knowledge of different types of texts better comprehend information in those texts (Duke \& Pearson, 2002; Meyer \& Rice, 1984; Stein \& Trabasso, 1982). Text represents a conversation between author and reader (Smith, 1982), called student-text interaction (Readence et al., 1989). Texts should be appropriate to student ages and experiences (Duke \& Pearson), with selection based on vocabulary, sentence structure, text length, elaboration, coherence and unity, text structure, familiarity with content and background knowledge, and ability to interest students (Ryder \& Graves, 1994). Readability involves text language, text organization and structure, student's language (McKenna \& Robinson, 2002), sentence length, vocabulary, grammatical complexity, organization, cohesion, abstractness, clarity, and assumptions about prior knowledge (Miller \& McKenna, 1989). Understandability, usability, and interestability are also factors in selecting texts (Vacca \& Vacca, 2002). Syntax, structure, and arrangement of ideas play significant roles in students' ability to derive meaning from text, even if students are unaware of structure (Collins, 1994). Text structure is crucial to learning and memory, and knowledge of such is dependent on age and ability (Collins; Vacca, 2002). Content areas present ideas differently, using different vocabulary, syntax, and structure.

Knowledge of vocabulary is crucial to comprehension (Beck, Perfetti, \& McKeown, 1982; Nagy, 1998; National Reading Panel (NRP), 2000; Ryder \& Graves, 1994). Vocabulary is best learned when words are introduced in groups sharing common characteristics or relationships (Nagy \& Anderson, 1984; 
Snow, 2002). Words not in the learner's oral vocabulary will not be understood when encountered in text (NRP). Students build vocabulary through repeated exposure to new words and definitions and through contextual use of words (NRP; Stahl, 1986). Content area vocabulary is specialized and technical in nature (Baer \& Nourie, 1993; Bryant et al., 1999).

Students allowed to self-select reading materials seem to select narratives over expository texts (Graesser, 1981). In elementary grades, students learn to read from narrative texts, transitioning to reading to learn from expository texts at about the fourth grade (Snow, 2002). Expository text, which is used almost exclusively in content areas such as agriscience, is generally more complex, diverse, and challenging. Students may struggle with expository text and lose interest more easily than with narrative text.

\section{Teacher Variables}

Teachers play significant roles in developing proficient readers (Duffy, 1993; Snow, 2002). Teachers who encourage reading are often readers themselves and demonstrate that attitude to students through expectations of students to think and read within the discipline (Readence et al., 1989). Stemming from preparation in content area reading, teachers who facilitate reading processes possess a deep knowledge of reading processes and comprehension and implement research-based instructional strategies into teaching.

Teachers are reluctant to employ reading strategies in content areas (Barry, 2002; Bean, 1997). Reasons for reluctance include 1) perceived inadequacy to handle reading problems; 2) lack of time for reading instruction; 3) denial of importance and responsibility for teaching reading techniques (D'Arcangelo, 2002; Forget \& Bottoms, 2000; Ivey, 2002; Jacobs, 2002; Moore et al., 1999; Vaughn, Klinger, \& Bryant, 2001); and 4) lack of knowledge or preparation in reading strategies (Barry; Bean; D'Arcangelo; Moore et al., 1999; Rhoder, 2002; Stewart \& O’Brien, 1989; Vaughn et al.). Content area teachers even strive to minimize reading and writing in their classes (Allen, 2000; Cziko, 1998).

A teacher's attitude toward reading affects student performance (Readence et al., 1989). Teachers should be enthusiastic about reading, rather than discouraging or simply assigning reading as busy work (Readence et al.; Ryder \& Graves, 1994). Teachers who model good reading skills and comprehension encourage students to read (Forget \& Bottoms, 2000; Ivey, 2002; NRP, 2000; Rhoder, 2002). Teachers should read widely in their field to bring new information and ideas into courses (Readence et al.). Support and encouragement provided to students help with safety and comfort while reading and improve motivation to read. However, secondary teachers expect students to possess abilities necessary to read in content areas (Readence et al., 1989; Snow, 2002) and perceive their primary function as preparing students in content for further education (Moore et al., 1999; Vacca, 2002).

Content area teachers can impact students' comprehension by incorporating reading strategies into content area lessons (Baer \& Nourie, 1993; Vacca, 2002). Instruction in and application of reading strategies requires "explanation, modeling, practice, and application" (Vacca, p. 194). When teachers infused reading strategies into content area lessons and developed structured reading assignments, student performance and learning also increased (Forget \& Bottoms, 2000; Meltzer, 2001).

Teacher preparation significantly impacts content area reading and leads to improved student reading performance (Meltzer, 2001; Snow, 2002; Williams, 2002). Little attention has been given to "preparing teachers to develop the skills they need to promote reading comprehension, ensure content learning through reading, and deal with differences in comprehension skills that their students display" (Snow, p. xii). Teachers prepared in reading strategy utilization teach students about strategies, explain their importance, and teach how to use strategies (Duffy, Roehler, Meloth, \& Vavrus, 1986; Duffy et al., 1987). Teachers who are prepared with, use, and accommodate content area reading strategies daily are better able to assist struggling readers. Use of reading strategies often requires "substantial and intensive teacher preparation" (Williams, p. 255) and 
as many as 30 instances of practice before a new routine is implemented (Snow, 2002).

\section{Conclusions and Recommendations}

Teachers and contexts impact student reading comprehension. Agriscience teachers' attitude toward reading, personal reading habits, expectations for reading, knowledge of reading strategies, and teacher preparation in content area reading strategies affect student reading performance (Figure 1). Teachers who demonstrate the value of reading in their classes through personal reading, modeling of reading, and strategy use impact student reading comprehension and motivation to read in positive ways. Additionally, teachers who are prepared to use and reinforce content area reading strategies further improve student achievement.

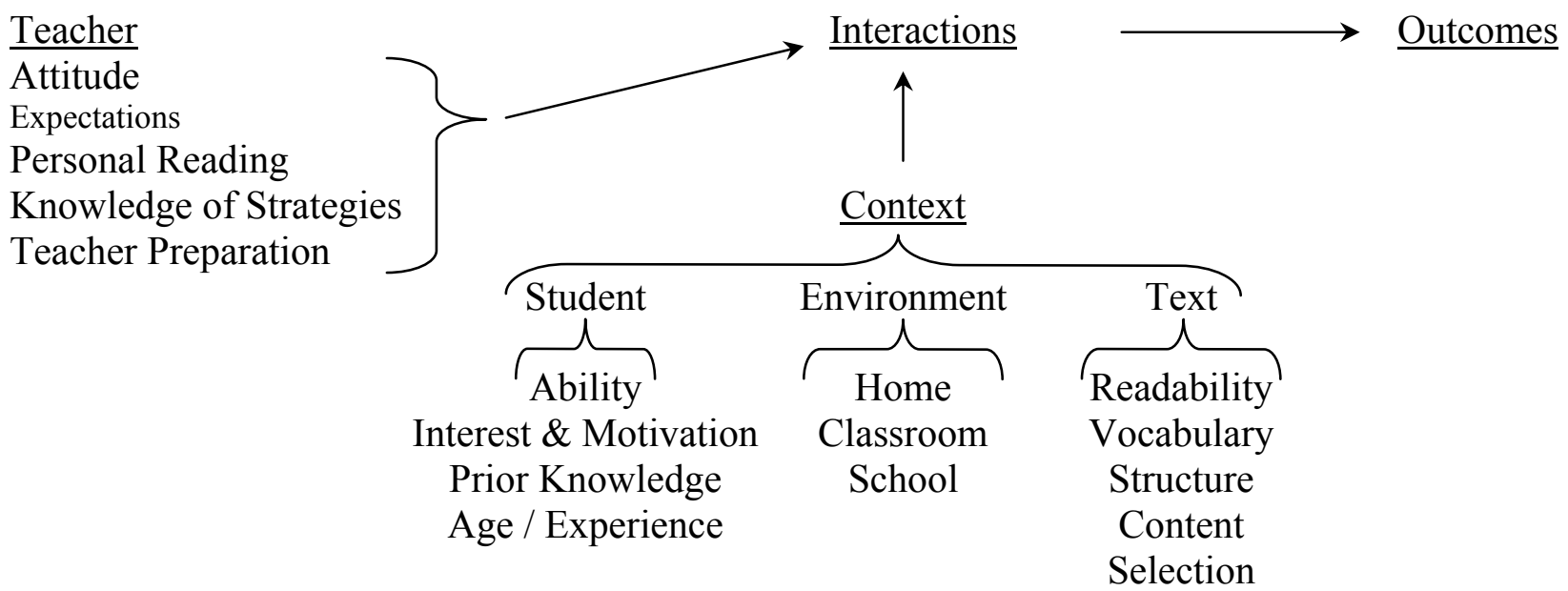

Figure 1. A model for the study of reading in secondary agriscience.

The context of agriscience (Figure 1) may be foreign and difficult for some students to comprehend. Learning in agriscience demands that students encounter text with specialized vocabulary, concepts, and forms. Contexts include home, classroom, and school environments and the readability, vocabulary, structure, content, and selection of agriscience texts. The student is also one facet of the context of reading and consists of the student's reading ability, interest in agriscience, motivation to read, prior knowledge, age, and experience. Contextual factors related to the student often vary from one student to another, leading to challenges in reinforcing content area reading.

Little research has been conducted to assess the impact of agriscience courses on student reading comprehension and performance, yet agriscience teachers are expected to contribute to students' overall academic performance. The lack of research and understanding of reading in agriscience leads to several general questions. How does the specialized context of agriscience and its many facets affect reading comprehension about agriculture? Further, agriscience teachers impact instruction and reading in agriscience, but how?

How does the context of agriscience impact student reading achievement and comprehension? What types of texts do students encounter in agriscience? What types of classroom reading resources are best suited for agriscience instruction, and what are the most effective means of incorporating reading into the curriculum? What is the readability of common agriscience texts? As students with variable prior knowledge, motivation, ability, and experience enroll in agriscience courses, how can the agriscience teacher tailor text use to encompass these ranges of attributes? How do, or can, agricultural education courses contribute to student success in 
reading? Research-based reading instruction and strategies that are effective in agriscience need to be identified. Given the current emphasis on student achievement and testing in reading, and the expectation that all subjects contribute to reading performance, there is a sense of urgency in pursuing the reading research agenda in agriscience.

If agriculture teachers can impact students' reading performance, more specific research questions need to be addressed to build the knowledge base. What are agriscience teachers' attitudes toward personal and agriscience reading? How does a teacher who values reading impact student reading performance compared to one who disregards reading in the classroom? How do agriscience teachers perceive their role in reinforcing student achievement in reading? What are their expectations for student reading in and about agriscience? How effectively do agriscience teachers assess their students' reading abilities? How prepared are agriscience teachers to teach using content area reading strategies? What reading strategies do teachers know how to use? What reading strategies are agriscience teachers currently employing?

Within the specialized context of agriscience, teachers have an opportunity to teach students how to comprehend and use texts for authentic experiences. Students may use agriscience texts to solve problems, find information, make evaluations, and reason critically about issues facing agriculture. Agriscience courses may offer opportunities for students to engage with reading in ways unlike those encountered in other academic courses. Teachers can take advantage of these opportunities to reinforce reading and strategy use if they are properly prepared.

Because teachers influence student reading through modeling, support, and employment of reading strategies, more research is needed to assess agriscience teachers' personal reading habits, knowledge of research-based reading strategies, attitudes toward reading, and teacher preparation in content area reading. Further, research is needed to identify the agriscience reading contexts and determine methods to employ that aid students in comprehending difficult and technical text. Further research is needed to determine how and why teachers select certain texts and reading resources for classroom instruction.

Researchers should use the proposed model for the study of reading in agriscience, or similar models, to further study questions and variables related to reading in agriscience. The questions presented in this paper are but the tip of the research iceberg. Further, teacher education faculty should reinforce the value of reading and strategy use to pre-service agriscience students. They should model an appreciation and utilization of reading as a necessary tool for lifelong success. Reading, understanding, and using a variety of texts will be necessary for student success, and all teachers should learn how to effectively teach and reinforce reading comprehension.

To some extent, all teachers, including agriscience teachers, are and must be teachers of reading. To ensure adequate student learning and to develop life-long learners, teacher educators should add research-based reading strategies to the arsenal of instructional techniques used to prepare future teachers. Pre-service teachers should teach, model, and use research-based reading strategies in their agriscience programs. Students graduating from these agriscience programs should possess the skills needed to effectively navigate texts, building comprehension in and about agriculture.

\section{References}

Allen, R. (2000). Before it's too late: Giving reading a last chance. Alexandria, VA: Association for Supervision and Curriculum Development.

Asher, S. R. (1980). Topic interest and children's reading comprehension. In R. J. Spiro, B. C. Bruce, \& W. F. Brewer (Eds.), Theoretical issues in reading comprehension (pp. 525-534). Hillsdale, NJ: Erlbaum.

Baer, G. T., \& Nourie, B. L. (1993). Strategies for teaching reading in the content areas. The Clearing House, 67(2), 121-122. 
Baldwin, R. S., Peleg-Bruckner, Z., \& McClintock, A. (1985). Effects of topic interest in children's' reading comprehension. Reading Research Quarterly, 10, 497-504.

Barry, A. L. (2002). Reading strategies teachers say they use. Journal of Adolescent and Adult Literacy, 46(2), 132-141.

Bean, T. W. (1997). Preservice teachers' selection and use of content area literacy strategies. The Journal of Educational Research, 90(3), 154-169.

Beck, I. L., Perfetti, C. A., \& McKeown, M. G. (1982). The effects of long-term vocabulary instruction on lexical access and reading comprehension. Journal of Educational Psychology, 74, 506-521.

Belcher, G., McCaslin, N. L., \& Headley, W. S. (1996). Implications of performance measures and standards for evaluation and assessment in agricultural education. Journal of Agricultural Education, 37(4), 1-7.

Bryant, D. P., Ugel, N., \& Thompson, S. (1999). Instructional strategies for content area reading instruction. Intervention in School and Clinic, 34(5), 293-302.

Collins, N. D. (1994). Metacognition and reading to learn. ERIC Clearinghouse on Reading, English, and Communication, Digest \#96. Retrieved July 20, 2004, from http://www.indiana.edu/ eric_rec/ieo/digest s/d96.html.

Conroy, C. A., \& Walker, N. J. (2000). An examination of academic and vocational subject matter in the aquaculture classroom. Journal of Agricultural Education, 41(2), 54-64.

Cooper, J. D. (2000). Literacy: Helping children construct meaning. Wilmington, MA: Houghton Mifflin.

Cziko, C. (1998). Reading happens in your mind, not in your mouth: Teaching \& learning "academic literacy" in an urban high school. Retrieved July 20, 2004, from http://www.wested.org/stratlit/prodeveol/hap pens.shtml.

D'Arcangelo, M. (2002). The challenge of content-area reading: A conversation with Donna Ogle. Educational Leadership, 60(15), 12-15.

Dole, J. A., Brown, K. J., \& Trathen, W. (1996). The effects of strategy instruction on the comprehension performance of at-risk students. Reading Research Quarterly, 31, 62-88.

Donahue, P. L., Voelk1, K. E., Campbell, J. R., \& Mazzeo, J. (1999). NAEP 1998 reading report card for the nation and states. Washington, D. C.: National Center for Educational Statistics. Retrieved June 6, 2003 from http://nces.ed.gov/nations reportcard//pubs/main1998/1999500.asp.

Duffy, G. G. (1993). Rethinking strategy instruction: Four teacher's development and their low achievers' understandings. Elementary School Journal, 93(3), 231-247.

Duffy, G. G., Roehler, L. R., Meloth, M. S., Polin, R., Rackliffe, G., \& Tracy, A., et al. (1987). Developing and evaluating measures associated with strategic reading. Journal of Reading Behavior, 19, 223-246.

Duffy, G. G., Roehler, L. R., Meloth, M. S., \& Vavrus, L. G. (1986). Conceptualizing instructional explanation. Teaching and Teacher Education, 2, 197-214.

Duke, N. K., \& Pearson, P. D. (2002). Effective practices for developing reading comprehension. In A. E. Farstrup \& S. J. Samuels (Eds.) What research has to say about reading instruction. Newark, DE: International Reading Association.

Dunkin, M. J., \& Biddle, B. J. (1974). The study of teaching. Washington, D. C.: University Press of America.

Forget, M., \& Bottoms, G. (2000). Academic and vocational teachers can improve the reading achievement of male career-bound students. Atlanta, GA: Southern Regional Education Board. 
Friend, R. (2001). Teaching summarization as a content area reading strategy. Journal of Adolescent and Adult Literacy, 44 (4), 320-339.

Gartin, S. A., Varner-Friddle, L., Lawrence, L. D., Odell, K. S., \& Rinehart, S. (1994). West Virginia secondary agriculture teachers' estimates of magazine article readability and reading grade levels of eleventh grade agricultural education students. Journal of Agricultural Education, 35(1), 49-53.

Gaultney, J. F. (1995). The effect of prior knowledge and metacognition on the acquisition of a reading comprehension strategy. Journal of Child Psychology, 59, 142-163.

Graesser, A. C. (1981). Prose comprehension beyond the word. New York: Springer-Verlag.

Guthrie, J. T., Van Meter, P., McCann, A. D., Wigfield, A., Bennett, L., \& Poundstone, C. C. (1996). Growth of literacy engagement: Changes in motivations and strategies during conceptoriented reading instruction. Reading Research Quarterly, 31, 306-332.

Hurst, B. (2001). ABCs of content area lesson planning: Attention, basics, and comprehension. Journal of dolescent \& Adult Literacy, 44(8), 692-693.

Irvin, J. L., \& Connors, N. A. (1989). Reading instruction in middle level schools: Results of a U.S. survey. Journal of Reading, 32, 306-311.

Ivey, G. (2002). Getting started: Manageable literacy practices. Educational Leadership, 60(3), 20-23.

Jacobs, V. A. (2002). Reading, writing, and understanding. Educational Leadership, 60(3), 58-61.

McKenna, M. C., \& Robinson, R. D. (2002). Teaching through text: Reading and writing in the content areas. Boston, MA: Allyn and Bacon.
Meltzer, J. (2001). Supporting adolescent literacy across the content areas: Perspectives on policy and practice. Washington, D.C.: Office of Educational Research and Improvement.

Meyer, B., \& Rice, E. (1984). The structure of text. In P. D. Pearson (Ed.), Handbook of reading research. New York: Longman.

Michiels-Bongaerts, M., \& Schmidt, H. $\mathrm{G}$. (1995). The relation between the nature of prior knowledge activated and information processing: To elaborate or to infer? (ERIC Document Reproduction Service No. ED 392831).

Miller, J. W., \& McKenna, M. C. (1989). Teaching reading in the elementary school. Scottsdale, AZ: Gorsuch Scarisbrick.

Moore, D. W., Alvermann, D. E., \& Hinchman, K. A. (2000). Struggling adolescent readers: A collection of teaching strategies. Newark, DE: International Reading Association.

Moore, D. W., Bean, T. W., Birdyshaw, D., \& Rycik, J. A. (1999). Adolescent literacy: A position statement for the commission on adolescent literacy of the International Reading Association. International Reading Association. Retrieved March 17, 2003, from http://www.reading.org/pdf/1036.pdf.

Nagy, W. E. (1998). Teaching vocabulary to improve comprehension. Newark, DE: International Reading Association.

Nagy, W. E., \& Anderson, R. C. (1984). How many words are there in printed school English? Reading Research Quarterly, 19, 304-330.

National Reading Panel. (2000). Teaching children to read: An evidencebased assessment of the scientific research literature on reading and its implications for reading instruction. Washington, D.C.: U.S. Department of Health and Human Services. 
Paris, S. G., \& Lindauer, B. K. (1976). The role of inference in children's comprehension and memory. Cognitive Psychology, 8, 217-227.

Pate, S. S. (1995). Using mapping to get the most out of reading. (ERIC Document Reproduction Service No. ED 381743).

Pressley, M., Symons, S., McGoldrick, J. A., \& Snyder, B. L. (1995). Reading comprehension strategies. In M. Pressley \& V. Woloshyn (Eds.), Cognitive strategy instruction that really improves children's academic performance. Cambridge, MA: Brookline Books.

Readence, J. E., Bean, T. W., \& Baldwin, R. S. (1989). Content area reading: An integrated approach. Dubuque, IA: Kendall/Hunt.

Rhoder, C. A. (2002). Mindful reading: Strategy instruction that facilitates transfer. Journal of Adolescent and Adult Literacy, 45, 498-512.

Ryder, R. J., \& Graves, M. F. (1994). Reading and learning in content areas. New York, NY: Macmillan College.

Schunk, D. H., \& Zimmerman, B. J. (1997). Developing self-efficacious readers and writers: The role of social and selfregulatory processes. In J. T. Guthrie \& A. Wigfield (Eds.), Reading for engagement: Motivating readers through integrated instruction. Newark, DE: International Reading Association.

Smith, F. (1982). Understanding reading (3rd ed.). New York: Holt, Rinehart \& Winston.

Snider, V. E. (1989). Reading comprehension performance of adolescents with learning disabilities. Learning Disability Quarterly, 12, 87-96.

Snow, C. (2002). Reading for Understanding: $\quad$ Toward an $R \& D$ Program in Reading Comprehension. Santa Monica, CA: The RAND
Corporation. Retrieved March 17, 2003, from http://www.rand.org/publications/ MR/MR1465.

Stahl, S. A. (1986). Three principles of effective vocabulary instruction. Journal of Reading, 29, 662-668.

Stanovich, K. E. (1986). Matthew effects in reading: Some consequences of individual differences in the acquisition of literacy. Reading Research Quarterly, 21, 380-407.

Stein, N. L., \& Trabasso, T. (1982). What's in a story: An approach to verbal comprehension and instruction. In R. Glaser (Ed.), Advances in instructional psychology (Vol. 2). Hillsdale, NJ: Erlbaum.

Stewart, R. A., \& O'Brien, D. G. (1989). Resistance to content area reading: A focus on preservice teachers. Journal of Reading, $32,396-401$.

Stewart, O., \& Tei, E. (1983). Some implications of metacognition in reading instruction. Journal of Reading, 27, 36-43.

Vacca, R. T. (2002). Making a difference in adolescents' school lives: Visible and invisible aspects of content area reading. In A. E. Farstrup \& S. J. Samuels (Eds.) What research has to say about reading instruction. Newark, DE: International Reading Association.

Vacca, R. T., \& Vacca, J. L. (2002). Content area reading: Literacy and learning across the curriculum. Boston: Allyn and Bacon.

Vaughn, S., Klinger, J. K., \& Bryant, D. P. (2001). Collaborative strategic reading as a means to enhance peer-mediated instruction for reading comprehension and content-area learning. Remedial \& Special Education, 22(2), 66-74.

Wigfield, A., \& Asher, S. R. (1984). Social and motivational influences on reading. In P. D. Pearson (Ed.), Handbook of reading research (pp.432-452). New York: Longman. 
Williams, J. P. (2002). Reading Samuels (Eds.) What research has to say comprehension strategies and teacher about reading instruction. Newark, DE: preparation. In A. E. Farstrup \& S. J. International Reading Association.

TRAVIS D. PARK is an Assistant Professor in the Department of Education at Cornell University, 420 Kennedy Hall, Ithaca, NY 14853. E-mail: tdp9@,cornell.edu.

ED OSBORNE is Professor and Department Chair of Agricultural Education and Communication at the University of Florida, 305 Rolfs Hall, P. O. Box 110540, Gainesville, FL 32611-0540. E-mail: ewo@ufl.edu. 